Research Article

\title{
Behaviour of Foam Concrete under Impact Loading Based on SHPB Experiments
}

\author{
Yongliang He, ${ }^{1,2}$ Mingshi Gao $\mathbb{D}^{1,2,3}$ Hongchao Zhao $\mathbb{D}^{3},{ }^{3,4}$ and Yichao Zhao $\mathbb{D}^{1,2}$ \\ ${ }^{1}$ School of Mines, Key Laboratory of Deep Coal Resource Mining, China University of Mining and Technology, Xuzhou, \\ Jiangsu 221116, China \\ ${ }^{2}$ The State Key Laboratory of Coal Resources and Safe Mining, China University of Mining and Technology, Xuzhou, \\ Jiangsu 221116, China \\ ${ }^{3}$ School of Geology and Mining Engineering, Xinjiang University, Urumqi, Xinjiang 830046, China \\ ${ }^{4}$ School of Civil, Mining and Environmental Engineering, University of Wollongong, Northfield, NSW 2500, Australia
}

Correspondence should be addressed to Mingshi Gao; cumt_gms@cumt.edu.cn

Received 25 February 2019; Revised 16 April 2019; Accepted 8 May 2019; Published 11 June 2019

Academic Editor: Miguel Neves

Copyright ( $\odot 2019$ Yongliang He et al. This is an open access article distributed under the Creative Commons Attribution License, which permits unrestricted use, distribution, and reproduction in any medium, provided the original work is properly cited.

This paper presents an innovative method for using foam concrete as a typical building material for soft structures in underground coal mines subjected to dynamic loading. To understand the behaviour of foam concrete under impact loading, a total of 30 specimens with a diameter of $50 \mathrm{~mm}$ and a height of $50 \mathrm{~mm}$ were experimentally tested using a $75 \mathrm{~mm}$ diameter split Hopkinson pressure bar (SHPB) device. The key parameters investigated in the present study included the type of foam concrete (fly ash and sand), the density of foam concrete $\left(1000,1200\right.$ and $\left.1400 \mathrm{~kg} / \mathrm{m}^{3}\right)$, and the impact velocity $(3.0,4.0,5.0,6.0$, and $7.0 \mathrm{~m} / \mathrm{s})$. Six specimens were also tested under static loading for comparison. The stress-strain curve of foam concrete under impact loading showed three stages, started with a linear elastic stage, followed by a yield stage and ended with a pore wall destruction stage. The test results also indicated that the dynamic increase factor, ultimate compressive strength, tenacity, and specific energy absorption increase with the strain rate under the same density. In particular, both the failure model and the behaviour of foam concrete were affected by the impact velocity. The findings of this research provide a reference for further research on the application of foam concrete in underground coal mines.

\section{Introduction}

Foam concrete is widely used as a sustainable building material in many infrastructures and constructions, such as the roof of a building $[1,2]$, the thermal insulation layer outside a concrete wall [3], the backfill of an abandoned mine, and the support system for an underground coal mine [4]. In addition, foam concrete is also widely utilized for the runway systems of airports [5], the storage of water in sandy areas, and the stabilization of nuclear buildings and can be applied in landscape gardens, shock-absorbing panels, bridge or bridge arch infill [6], and pipework protection [7]. Recently, foam concrete has been further introduced into coal mines as a soft structure to control the stability of the surrounding rock mass under dynamic loading.
The strong-soft-strong structural model features the excavation roadway at its centre. The rock mass within a coal mine surrounding an excavation roadway is divided into three structures from the centre outward: an internal strong structure, an intermediate soft structure, and an external strong structure. In contrast to the use of traditional anchor bolts and anchor cables, which contribute little to controlling the surrounding rock under dynamic loading (e.g., a rock burst), foam concrete plays a critical role in dissipating and absorbing the energy of rock bursts occurring throughout mine roadways. Figure 1 illustrates the strongsoft-strong structural model proposed by Gao et al. [8]. The internal strong structure, which is generally $6 \sim 12 \mathrm{~m}$ thick, constitutes the roadway support layer, which is used to maintain the stability of mine roadways by supporting and protecting them. The intermediate soft structure represents 
the area in which waves are eliminated and energy is absorbed; this zone is approximately $8 \sim 10 \mathrm{~m}$ thick. Finally, the external strong structure is a stable layer composed of the original rock mass that has not been disturbed by mining and extends throughout the entire formation. In this context, the use of foam concrete as the intermediate soft structural material plays an important role in preventing and controlling the occurrence of rock bursts and in supporting roadways.

The mechanical properties of foam concrete have been investigated extensively over the past few decades. Ramamurthy et al. [9] reviewed the classification of the properties of foam concrete and summarized the proportioning, preparation, consistency, stability, physical properties, mechanical properties, durability, and functional characteristics of foam concrete. Jones and McCarthy [10] noted that the foam concrete experienced less shrinkage due to drying when sand was used instead of fly ash because sand is more resistant to shrinkage than fly ash. Li et al. [11] analysed the void system of foam concrete and concluded that the microscopic distribution of voids affects the overall strength. Other studies have been conducted to better understand its physical and chemical properties. Habel et al. [12] and Liu et al. [13] studied the mechanical properties and microstructural characteristics of concrete. Wee et al. [14] and K. G. Babu and D. S. Babu [15] studied the preparation and mixing design of foam concrete specimens. Panesar [16] and Falliano et al. [17] studied the influences of foaming agents on the mechanical properties of foam concrete under static loading conditions. According to Falliano et al. [17] and Kearsley and Wainwright [18], the compressive strength of foam concrete with a density of $1000 \sim 1500 \mathrm{~kg} / \mathrm{m}^{3}$ was $2.8 \sim 19 \mathrm{MPa}$, and the compressive strength increased with the experimentation time. However, most previous studies that focused on the characteristics of foam concrete, including those conducted by Ramamurthy et al. [9], She et al. [19], Nambiar and Ramamurthy [20], Jones and McCarthy [21], Hajimohammadi et al. [22], and Ma and Chen [23], and the studies by Liu et al. [24], Zhu and Xie [25], Tian et al. [26], and Bagheri et al. [27], who examined the mechanical properties of foam concrete, were performed under static loading conditions.

Rock burst is one of the most serious dynamic disasters affecting the safety and efficiency of underground coal mines. As shown in the strong-soft-strong structural model [28], soft structural areas play a key role in dissipating and absorbing the energy released by rock burst events throughout mine roadways and are used to prevent their occurrence. The dynamic properties of foam concrete are important due to its rapid development and widely accepted application. This paper presented the results of an impact test on foam concrete by using a split Hopkinson pressure bar (SHPB) device to better understand the behaviour of foam concrete under dynamic loading as the soft structure in a coal mine roadway. The behaviour of foam concrete under static loading was presented as well.

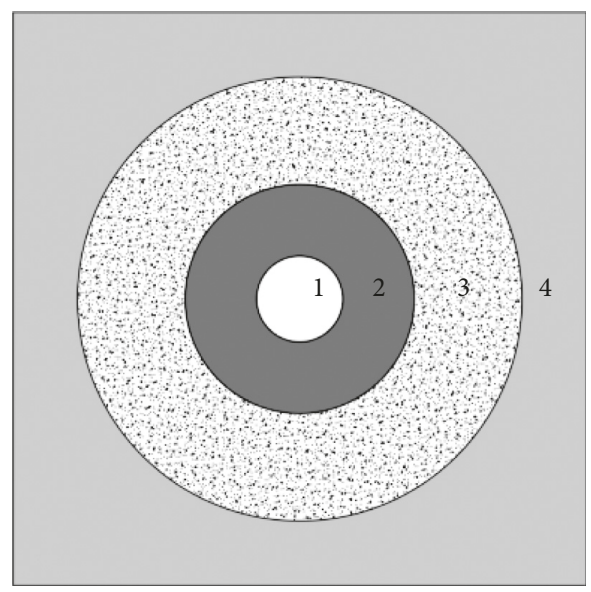

FIgURE 1: Strong-soft-strong structural model. 1, roadway; 2, internal strong structure $(6 \sim 12 \mathrm{~m}) ; 3$, intermediate soft structure $(8 \sim 10 \mathrm{~m}) ; 4$, external strong structure (the surrounding formation).

\section{Materials and Preparation of Specimens}

2.1. Materials. The constituent materials for foam concrete included river sand, fly ash, cement, foam agent, foam stabilizer, and tap water. More detailed information on the raw materials is listed in Table 1.

2.2. Mixing Design. The density of foam concrete is estimated according to the type and density of fly ash, sand, cement, and water. Considering design densities of 1,000 , 1,200 , and $1,400 \mathrm{~kg} / \mathrm{m}^{3}$, several foam concrete compositions using hydrogen peroxide as a foaming agent [29] were defined. The obtained compositions produced foam concrete mixtures with actual densities that do not match exactly with the design densities (although it is possible to recalculate the output density as described in Appendix just by adjusting the design densities until output density is the desired one). In the actual experiment, we used the mixture with the actual density indicated in Table 2.

2.3. Preparation of Specimens. In the study, the mixing process has an important influence on the bubble density, distribution, and shape in foam concrete. The mixing process was as follows:

(1) A common tilt drum was used to mix the cement, fly ash or sand, and foam stabilizer (calcium stearate).

(2) The mixed material was dry mixed for approximately 1 min using a tilt drum. The mixture was mixed until it was homogeneous and contained no lumps of undispersed cement and sand.

(3) After stirring, the water and foaming agent were added. After stirring for $1 \mathrm{~min}$, the mixed material was poured into preprepared $\varnothing 50 \times 50$ cylindrical plastic moulds and $\varnothing 50 \times 100$ cylindrical aluminium moulds [30]. The specimens did not require vibration. Figures 2 and 3 show the $\varnothing 50 \times 50$ cylindrical 
TABLE 1: Materials used and their descriptions.

\begin{tabular}{|c|c|}
\hline Material & Description \\
\hline $\begin{array}{l}\text { Portland } \\
\text { cement }\end{array}$ & $\begin{array}{c}\text { 42.5R ordinary Portland cement }(\mathrm{PC}) \text { with a density of } 3,150 \mathrm{~kg} / \mathrm{m}^{3} \text {, an initial setting time of } 50 \mathrm{~min} \text {, and a final setting } \\
\text { time of } 3 \mathrm{~h} \text { and } 30 \mathrm{~min}\end{array}$ \\
\hline River sand & $\begin{array}{c}\text { Sand with a density of } 2,520 \mathrm{~kg} / \mathrm{m}^{3} \text {, a particle size of less than } 5 \mathrm{~mm} \text {, and an average fineness of } 2.50 \text { was used as coarse } \\
\text { aggregate }\end{array}$ \\
\hline Fly a & Fly ash with an average grain diameter of $1-15 \mu \mathrm{m}$, class I parameters, and a density of $2,400 \mathrm{~kg} / \mathrm{m}^{3}$ \\
\hline Foar & Industrial hydrogen peroxide at a $30 \%$ concentration \\
\hline Catalyst & $\mathrm{MnO}_{2}$ catalysis \\
\hline Foam stabilizer & Calcium stearate $\left(\mathrm{C}_{36} \mathrm{H}_{70} \mathrm{CaO}_{4}\right)$ \\
\hline Water & Tap water \\
\hline
\end{tabular}

TABLe 2: Mixing design for foam concrete with different densities $\left(\right.$ per $\mathrm{m}^{3}$ ).

\begin{tabular}{lcccccc}
\hline Design plastic density $\left(\mathrm{kg} / \mathrm{m}^{3}\right)$ & Cement type & Cement $(\mathrm{kg})$ & Sand $(\mathrm{kg})$ & Fly ash $(\mathrm{kg})$ & Water $(\mathrm{kg})$ & Foam agent $(\mathrm{kg})$ \\
\hline \multirow{2}{*}{1000} & \multirow{2}{*}{ PC } & 658.77 & 164.69 & - & 329.38 & 5.61 \\
& & 658.17 & - & 164.54 & 329.08 & 5.57 \\
\hline \multirow{2}{*}{1200} & \multirow{2}{*}{ PC } & 765.19 & 191.30 & - & 382.60 & 4.23 \\
& & 764.38 & - & 191.10 & 382.19 & 4.19 \\
\hline \multirow{2}{*}{1400} & \multirow{2}{*}{ PC } & 864.68 & 216.17 & - & 432.34 & 2.94 \\
& & 863.64 & - & 215.91 & 431.82 & 2.89 \\
\hline
\end{tabular}

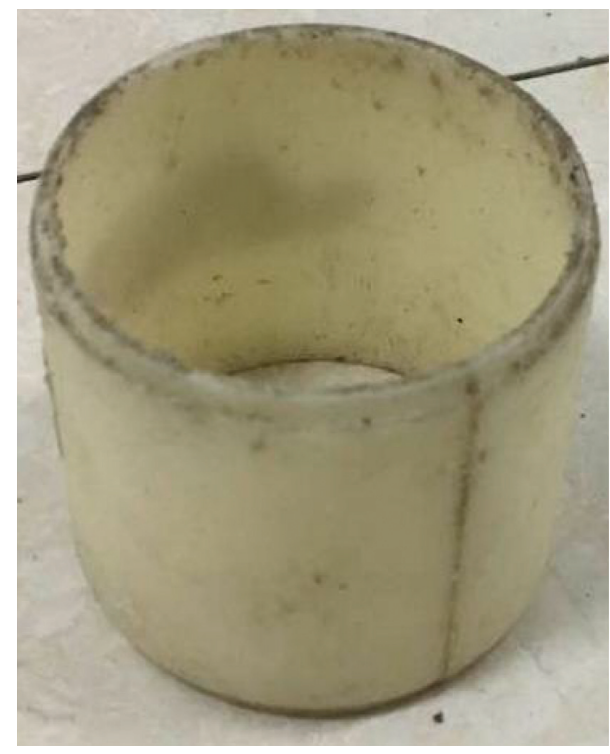

FIgURE 2: $\varnothing 50 \times 50$ plastic mould.

plastic mould and $\varnothing 50 \times 100$ aluminium mould, respectively.

(4) The specimens were placed under standard curing conditions (temperature $=20 \pm 2{ }^{\circ} \mathrm{C}$, relative humidity $>95 \%$ ) for $24 \mathrm{~h}$ and then removed from the mould. The specimens were maintained under standard curing conditions for 28 days, after which the cylindrical specimens were tested with each impact speed of the SHPB.

The actual density was determined through weighing the foam concrete sample and measuring the weights and volumes of the moulds. The acceptable tolerance between the

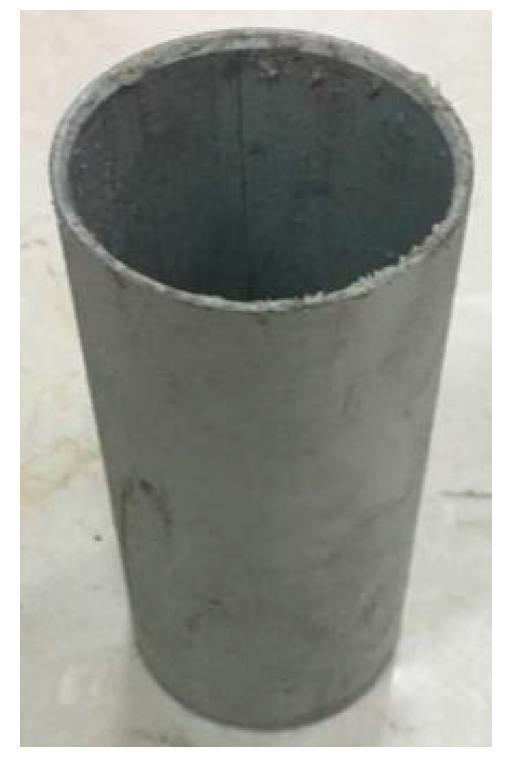

Figure 3: $\varnothing 50 \times 100$ aluminium mould.

design density and actual density was fixed as $\pm 50 \mathrm{~kg} / \mathrm{m}^{3}$ for the wet density of foam concrete.

Before the experiment, the actual density of each specimen was measured, and each specimen was given a unique identification number. Table 3 shows the design density, specimen number, actual density, loading condition, and impact velocity of both foam concrete with sand and foam concrete with fly ash. A total of 30 specimens were tested under dynamic loading condition, and 6 reference specimens were tested under static loading condition for comparison. The type of foam concrete, design density, and serial number can be identified by the unique specimen number as listed in Table 2. The specimen number consists of the type of foam 
TABLE 3: Design density and actual density of each tested sample.

\begin{tabular}{|c|c|c|c|c|c|c|c|c|}
\hline $\begin{array}{l}\text { Foam } \\
\text { concrete }\end{array}$ & $\begin{array}{c}\text { Design plastic density } \\
\left(\mathrm{kg} / \mathrm{m}^{3}\right)\end{array}$ & $\begin{array}{l}\text { Specimen } \\
\text { number }\end{array}$ & $\begin{array}{l}\text { Specimen diameter } \\
(\mathrm{mm})\end{array}$ & $\begin{array}{c}\text { Specimen } \\
\text { height } \\
(\mathrm{mm})\end{array}$ & $\begin{array}{l}\text { Weight } \\
\text { (g) }\end{array}$ & $\begin{array}{l}\text { Actual } \\
\text { density } \\
\left(\mathrm{kg} / \mathrm{m}^{3}\right)\end{array}$ & $\begin{array}{c}\text { Impact } \\
\text { velocity } \\
(\mathrm{m} / \mathrm{s})\end{array}$ & $\begin{array}{l}\text { Loading } \\
\text { condition }\end{array}$ \\
\hline \multirow{18}{*}{$\begin{array}{l}\text { Foam } \\
\text { concrete } \\
\text { with sand }\end{array}$} & \multirow{6}{*}{1000} & S-0-1 & 50.5 & 100.2 & 199.3 & 993.5 & 0 & Static loading \\
\hline & & S- $0-2$ & 51.3 & 49.3 & 100.1 & 982.8 & 3 & \multirow{5}{*}{$\begin{array}{l}\text { Dynamic } \\
\text { loading }\end{array}$} \\
\hline & & S- $0-3$ & 50.3 & 49.8 & 99.3 & 1004.0 & 4 & \\
\hline & & S- $0-4$ & 48.9 & 50.5 & 98.5 & 1039.1 & 5 & \\
\hline & & S- $0-5$ & 51.6 & 50.4 & 101.3 & 961.6 & 6 & \\
\hline & & S-0-6 & 52.0 & 49.0 & 102.6 & 986.4 & 7 & \\
\hline & \multirow{6}{*}{1200} & S-2-1 & 50.2 & 100.3 & 240.2 & 1210.6 & 0 & \multirow[t]{2}{*}{ Static loading } \\
\hline & & $S-2-2$ & 50.3 & 50.6 & 119.5 & 1189.1 & 3 & \\
\hline & & S-2-3 & 51.0 & 50.1 & 121.2 & 1184.8 & 4 & \multirow{4}{*}{$\begin{array}{l}\text { Dynamic } \\
\text { loading }\end{array}$} \\
\hline & & $S-2-4$ & 51.1 & 50.3 & 120.3 & 1166.8 & 5 & \\
\hline & & S-2-5 & 49.1 & 51.6 & 119.6 & 1224.8 & 6 & \\
\hline & & S-2-6 & 51.3 & 50.3 & 121.9 & 1173.1 & 7 & \\
\hline & \multirow{6}{*}{1400} & S-4-1 & 50.5 & 99.8 & 280.1 & 1401.9 & 0 & \multirow{6}{*}{$\begin{array}{c}\text { Static loading } \\
\text { Dynamic } \\
\text { loading }\end{array}$} \\
\hline & & S-4-2 & 50.0 & 50.3 & 139.7 & 1415.2 & 3 & \\
\hline & & S-4-3 & 49.9 & 50.5 & 140.5 & 1423.4 & 4 & \\
\hline & & S- $4-4$ & 51.3 & 50.6 & 141.3 & 1351.7 & 5 & \\
\hline & & S- $4-5$ & 50.8 & 49.9 & 138.9 & 1374.1 & 6 & \\
\hline & & S-4-6 & 49.2 & 50.4 & 138.3 & 1444.1 & 7 & \\
\hline \multirow{18}{*}{$\begin{array}{l}\text { Foam } \\
\text { concrete } \\
\text { with fly ash }\end{array}$} & \multirow{6}{*}{1000} & F-0-1 & 51.0 & 101.2 & 198.3 & 959.7 & 0 & \multirow[t]{2}{*}{ Static loading } \\
\hline & & F- $0-2$ & 50.2 & 50.1 & 99.9 & 1008.0 & 3 & \\
\hline & & F- $0-3$ & 49.2 & 51.1 & 99.1 & 1020.6 & 4 & \multirow{4}{*}{$\begin{array}{l}\text { Dynamic } \\
\text { loading }\end{array}$} \\
\hline & & F- $0-4$ & 51.2 & 49.4 & 99.6 & 979.8 & 5 & \\
\hline & & F- $0-5$ & 51.6 & 47.2 & 98.9 & 1002.5 & 6 & \\
\hline & & F-0-6 & 49.3 & 51.4 & 99.7 & 1016.6 & 7 & \\
\hline & & F-2-1 & 50.2 & 99.9 & 242.3 & 1226.1 & 0 & \multirow[t]{2}{*}{ Static loading } \\
\hline & \multirow{5}{*}{1200} & F-2-2 & 50.2 & 49.7 & 119.8 & 1218.5 & 3 & \\
\hline & & F-2-3 & 49.4 & 50.9 & 118.1 & 1211.2 & 4 & \multirow{4}{*}{$\begin{array}{l}\text { Dynamic } \\
\text { loading }\end{array}$} \\
\hline & & F- $2-4$ & 49.6 & 49.2 & 118.3 & 1245.0 & 5 & \\
\hline & & F-2-5 & 50.2 & 49.4 & 120.8 & 1236.1 & 6 & \\
\hline & & F-2-6 & 49.9 & 49.5 & 116.8 & 1207.2 & 7 & \\
\hline & \multirow{6}{*}{1400} & F-4-1 & 50.3 & 99.6 & 275.3 & 1391.7 & 0 & \multirow{6}{*}{$\begin{array}{c}\text { Static loading } \\
\text { Dynamic } \\
\text { loading }\end{array}$} \\
\hline & & F- $4-2$ & 50.1 & 49.3 & 135.8 & 1398.0 & 3 & \\
\hline & & F- $4-3$ & 51.0 & 50.4 & 143.9 & 1398.4 & 4 & \\
\hline & & F- $4-4$ & 50.1 & 50.6 & 141.6 & 1420.3 & 5 & \\
\hline & & F- $4-5$ & 50.6 & 48.4 & 138.7 & 1425.8 & 6 & \\
\hline & & F- $4-6$ & 50.8 & 49.5 & 139.7 & 1393.1 & 7 & \\
\hline
\end{tabular}

concrete (S-foam concrete with sand or F-foam concrete with fly ash), design density $\left(0-1000 \mathrm{~kg} / \mathrm{m}^{3}, 2-1200 \mathrm{~kg} / \mathrm{m}^{3}\right.$, or $4-$ $\left.1400 \mathrm{~kg} / \mathrm{m}^{3}\right)$, and serial number $(1,2,3,4,5$, or 6$)$.

\section{Experimental Procedure}

3.1. Testing Setup and Methodology. Figure 4 shows a schematic diagram of the SHPB apparatus [31,32], and Figure 5 shows photos of the SHPB device and velometer. For the impact compression test, a $75 \mathrm{~mm}$ diameter SHPB device was used consisting of the main body and measurement system. The incident bar and transmission bar were made of $48 \mathrm{CrMoA}$ and were characterized by Young's modulus of $210 \mathrm{GPa}$, a density of $7,850 \mathrm{~kg} / \mathrm{m}^{3}$, and a stress wave velocity of $5,172 \mathrm{~m} / \mathrm{s}$. Figure 6 presents a schematic illustration of the dynamic test under partial magnification. The incident signal $\varepsilon_{\mathrm{I}}\left(X_{\mathrm{G} 1}, t\right)$ and reflected signal $\varepsilon_{\mathrm{R}}\left(X_{\mathrm{G} 1}, t\right)$ were measured by strain gauge $G_{1}$ affixed to the incident bar, and the transmitter signal $\varepsilon_{\mathrm{T}}\left(X_{\mathrm{G} 1}, t\right)$ was measured using strain gauge $G_{2}$ affixed to the transmission bar.
3.2. Data Processing. Because the strain of the specimen can be deduced from the displacement of the specimen at both ends, the average stress and average strain can express the situation of the specimen:

$$
\begin{aligned}
& \dot{\varepsilon}=\frac{C_{0}}{L_{\mathrm{s}}}\left[\varepsilon_{\mathrm{i}}(t)-\varepsilon_{\mathrm{r}}(t)-\varepsilon_{\mathrm{t}}(t)\right], \\
& \varepsilon=\frac{C_{0}}{L_{\mathrm{s}}} \int_{0}^{\mathrm{t}}\left[\varepsilon_{\mathrm{i}}(t)-\varepsilon_{\mathrm{r}}(t)-\varepsilon_{\mathrm{t}}(t)\right] d t, \\
& \sigma=\frac{A_{0}}{2 A_{\mathrm{s}}} E_{0}\left[\varepsilon_{\mathrm{i}}(t)-\varepsilon_{\mathrm{r}}(t)-\varepsilon_{\mathrm{t}}(t)\right],
\end{aligned}
$$

where $\dot{\varepsilon}$ is the strain rate; $\varepsilon$ is the axial strain; $\sigma$ is the axial stress; $\varepsilon_{\mathrm{i}}(t), \varepsilon_{\mathrm{r}}(t)$, and $\varepsilon_{\mathrm{t}}(t)$ are the measured incident, reflected, and transmitted strain histories, respectively, of the SHPB; $A_{0}$ is the cross-sectional area of the bar; $C_{0}$ and $E_{0}$ are Young's modulus and stress wave speed, respectively, of the 


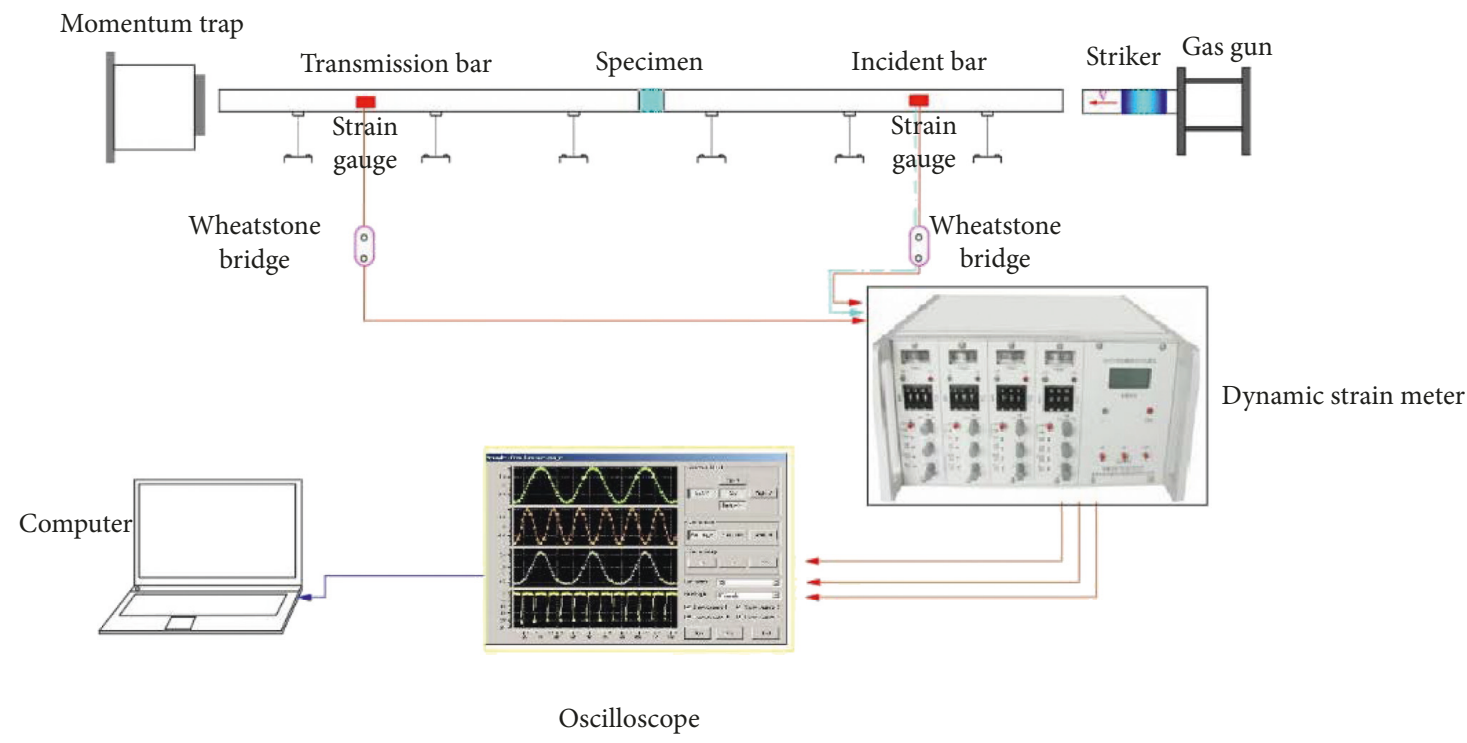

Figure 4: Schematic illustration of the SHPB device.
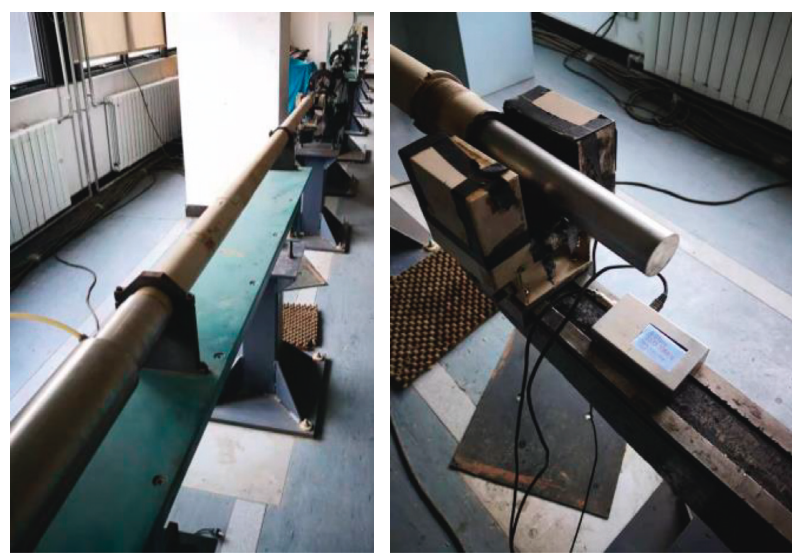

FIGURE 5: SHPB device and velometer.

bar; and $L_{\mathrm{s}}$ and $A_{\mathrm{s}}$ are the length and initial cross-sectional area, respectively.

When the stress in the specimen is uniform, we have

$$
\varepsilon_{\mathrm{i}}(t)+\varepsilon_{\mathrm{r}}(t)=\varepsilon_{\mathrm{t}}(t) .
$$

This equation can be simplified into the following:

$$
\begin{aligned}
& \dot{\varepsilon}=-\frac{2 C_{0}}{L_{\mathrm{s}}} \varepsilon_{\mathrm{r}}(t), \\
& \varepsilon=-\frac{2 C_{0}}{L_{\mathrm{s}}} \int_{0}^{\mathrm{t}} \varepsilon_{\mathrm{r}}(t) d t, \\
& \sigma=\frac{A_{0}}{A_{\mathrm{s}}} E_{0} \varepsilon_{\mathrm{t}}(t) .
\end{aligned}
$$

3.2.1. Dispersion Effect. All aspects of the triangular stress pulse and half-sine stress pulse can be obtained from theoretical research, experimental studies, and numerical

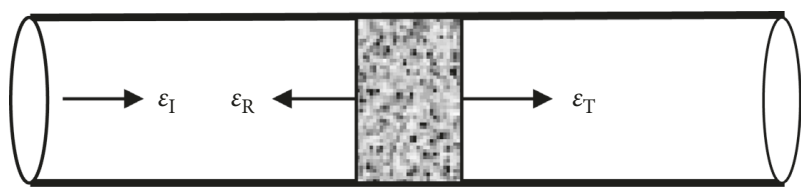

Figure 6: Schematic illustration of the dynamic test under partial magnification.

simulations. The traditional rectangular stress pulse displays a smaller dispersion effect. Moreover, the half-sine stress pulse is more controllable than the triangular stress pulse in the propagation process, allowing the dispersion effect to be effectively reduced [33]. For pulses in practical applications, shaping technology can effectively reduce the dispersion effect, thereby increasing the accuracy of the experiment.

3.2.2. Stress Equilibrium. The stress distribution in the specimen is the most significant at the beginning of the impact compression, and the stress distribution becomes uniform over time. In the early stage of deformation, the stress distribution [34] is caused mainly by the different stress levels at both ends of the specimen and is accompanied by large oscillations.

The one-dimensional stress wave equation reveals the following:

$$
\begin{aligned}
& \sigma_{1(t)}=\frac{A_{0}}{A_{\mathrm{s}}} E_{0}\left[\varepsilon_{\mathrm{i}(t)}+\varepsilon_{\mathrm{r}(t)}\right], \\
& \sigma_{2(t)}=\frac{A_{0}}{A_{\mathrm{s}}} E_{0} \varepsilon_{\mathrm{t}(t)},
\end{aligned}
$$

where $\sigma_{1(t)}$ and $\sigma_{2(t)}$ are the stresses at the left and right ends of the specimen, respectively.

Before the specimen fails, the stress will reach an equilibrium state; therefore, as the stress pulse propagates through the specimen, the specimen maintains a stable stress 
equilibrium state. If the propagation and attenuation of the stress wave are not considered within the specimen and the stress is evenly distributed in the specimen, then

$$
\sigma_{1(t)}=\sigma_{2(t)} .
$$

The nonuniformity of the internal stress of the specimen is denoted as $\alpha_{(t)}$; thus,

$$
\alpha_{(t)}=\frac{2\left|\sigma_{1(t)}-\sigma_{2(t)}\right|}{\sigma_{1(t)}+\sigma_{2(t)}} .
$$

When $\alpha_{(t)}<5 \%$, the stress distribution in the specimen can be approximated as uniform.

3.3. Constant Strain Rate Loading. The constant strain rate loading of a specimen affects the accuracy of the test results. During an experiment, a constant strain rate allows the original independent variables to be given by a fixed parameter. Furthermore, a constant strain rate allows for a better understanding of the properties of the material and enables the effect of the transverse inertial effect on the test to be reduced.

\section{Experimental Results and Discussions}

4.1. Failure Modes. Under impact compression conditions, the foam concrete exhibited different damage modes under different impact velocities related to the different densities. During the impact process, the foam concrete did not suffer damage instantaneously; instead, damage was a dynamic process. The microdamage inside the foam concrete gradually evolved before finally causing visible damage. According to an analysis of the degree of damage of the specimen, a higher degree of damage occurred with an increase in the impact velocity at the same density, and a lower-density specimen suffered a higher degree of damage at the same impact speed. The failure mode presented as layer-by-layer collapse under impact loading, as shown in Figure 7.

\subsection{Behaviour of Foam Concrete under Impact Loading}

4.2.1. Stress-Strain Curves. The dynamic compression stress-strain curves of the foam concrete specimens with sand with densities of $1,000,1,200$, and $1,400 \mathrm{~kg} / \mathrm{m}^{3}$ are shown for impact velocities of $4.0,5.0$, and $6.0 \mathrm{~m} / \mathrm{s}$ in Figure 8-10.

The dynamic compression stress-strain curves of the foam concrete specimens with fly ash with densities of 1,000 , 1,200 , and $1,400 \mathrm{~kg} / \mathrm{m}^{3}$ are shown for impact velocities of 4.0 , 5.0 , and $6.0 \mathrm{~m} / \mathrm{s}$ in Figure 11-13.

4.2.2. Three-Stage Response under Impact Loading. The peak stress value increased as the impact velocity increased for both the foam concrete with sand stress-strain curves and the foam concrete with fly ash stress-strain curves. As Figure 14 shows, the dynamic failure of foam concrete could be divided into three stages: a linear elastic stage, yield stage, and pore wall failure stage.

The linear elasticity stage (I): at the beginning of loading, the pore structure of foam concrete supported a certain pressure, and the stress-strain curve approximately followed a linear elastic behaviour, indicating that the initial pore spaces within the foam concrete cannot be penetrated in time and that there is no typical compaction stage. The stress and strain were approximately linearly proportional.

The yielding stage (II): as the load continued to increase and ultimately exceeded the maximum pressure of the pore structure of the foam concrete specimen, the plastic strain increased considerably, and the pores of the foam concrete began to exhibit plastic collapse, suffering brittle damage.

The pore wall destruction stage (III): the pores of the foam concrete expanded rapidly under dynamic loading after the peak stress value was reached, and the foam concrete specimen began to display macroscopic damage. When the stress value reached the maximum stress value, the pore walls within the foam concrete began to be destroyed during the compaction process. The compressive capacity of the specimen gradually decreased, and a macroscopic fracture surface formed inside the foam concrete specimen. When the pore structure of the foam concrete was completely destroyed, the specimen was no longer subjected to the load.

At the early stage of loading, the stress-strain relationship of the foam concrete was linear; the incident energy of the incoming bar was transformed into elastic energy within the foam concrete. As the load increased, the spacing between the voids within the foam concrete could not bear the load during the yielding stage, and either plastic or brittle failure occurred between the pore walls; the incident energy of the incident bar was transformed into plastic deformation of the foam concrete. When the load reached the peak value, the foam concrete expanded and ruptured; thus, the entire structure of the foam concrete was destroyed, and the specimen was no longer subjected to the load.

Several studies in the literature have shown that the use of fly ash instead of a certain amount of cement or sand can improve the performance of cement mortar and the compressive strength increases with increasing density $[9,25]$. Another study by Ramamurthy and Narayanan [35] showed that at densities of $1,000,1,200$, and $1,400 \mathrm{~kg} / \mathrm{m}^{3}$ and under the same conditions, foam concrete with fly ash has a higher compressive strength than foam concrete with sand.

\subsection{Impact Mechanical Properties}

4.3.1. Strength Properties. The dynamic increase factor (DIF) was used to describe the degree of enhancement under the impact of foam concrete during the impact state. The DIF is an important index of the compressive strength of a material under impact loading and is expressed as follows:

$$
\mathrm{DIF}=\frac{f_{\mathrm{c}, \mathrm{d}}}{f_{\mathrm{c}, \mathrm{s}}},
$$

where $f_{\mathrm{c}, \mathrm{d}}$ is the compaction compression strength and $f_{\mathrm{c}, \mathrm{s}}$ is the quasistatic pressure strength. 


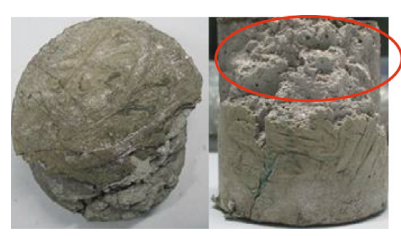

(a)

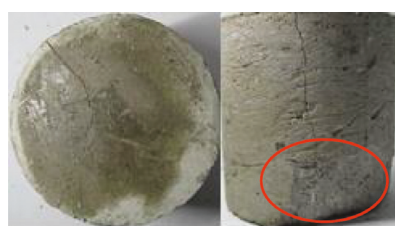

(b)

FIgURE 7: Typical failure modes of foam concrete under impact loading. (a) S-4-5. (b) S-0-3.

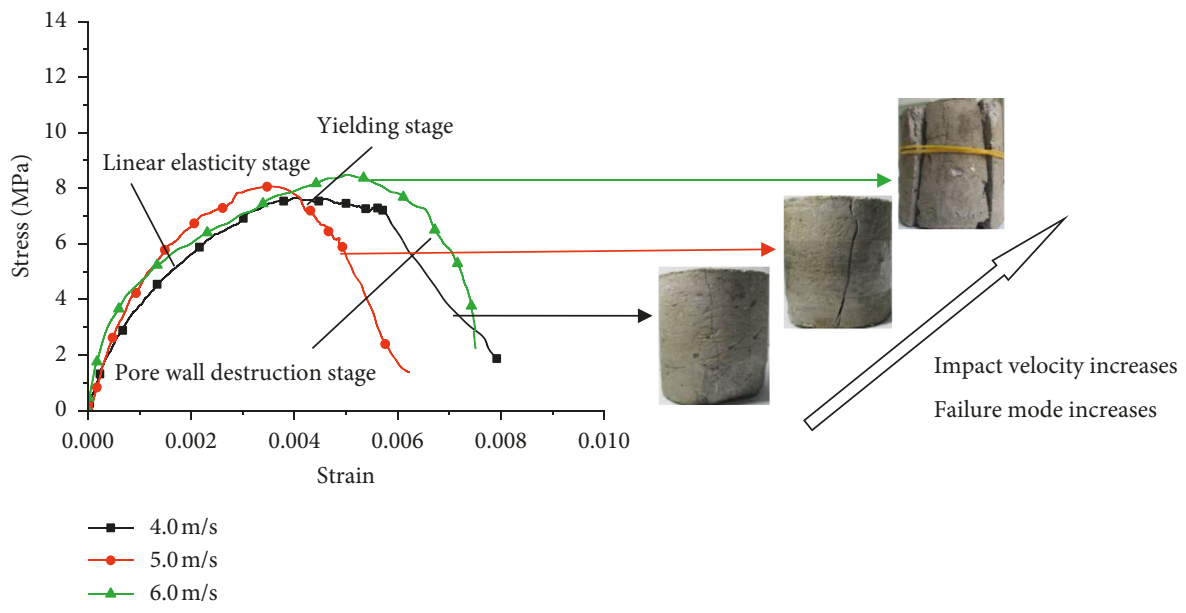

FIGURE 8: Foam concrete with sand stress-strain curve at $1,000 \mathrm{~kg} / \mathrm{m}^{3}$.

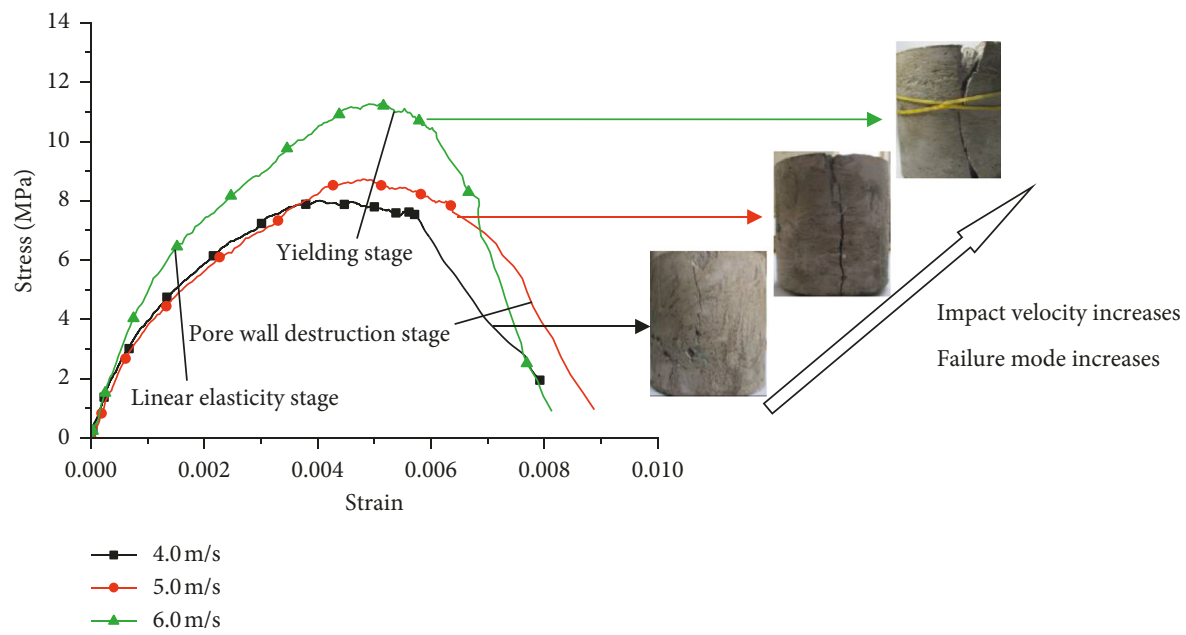

Figure 9: Foam concrete with sand stress-strain curve at $1,200 \mathrm{~kg} / \mathrm{m}^{3}$.

As shown in Figure 15, in the relationship between the DIF and strain rate, the DIF increased with the strain rate. The degree of damage of the foam concrete increased with an increase in the strain rate via the destruction of the foam concrete due to internal-external crack formation and development; the formation of new cracks required additional energy. A faster impact caused more cracks to form, and thus, more energy was consumed. Additionally, the DIF decreased with an increase in the density of the foam concrete.
4.3.2. Strain Rate and Ultimate Compressive Strength. The experiments in this study showed that the dynamic ultimate compressive strength of concrete increases with the strain rate, and studies have shown that the compressive strength increases as the strain rate increases. Figure 16 presents the relationship between the strain rate and ultimate compressive strength and shows that the dynamic mechanical properties of foam concrete exhibited a strain rate correlation similar to that of conventional concrete. The dynamic ultimate compressive strength of foam concrete 


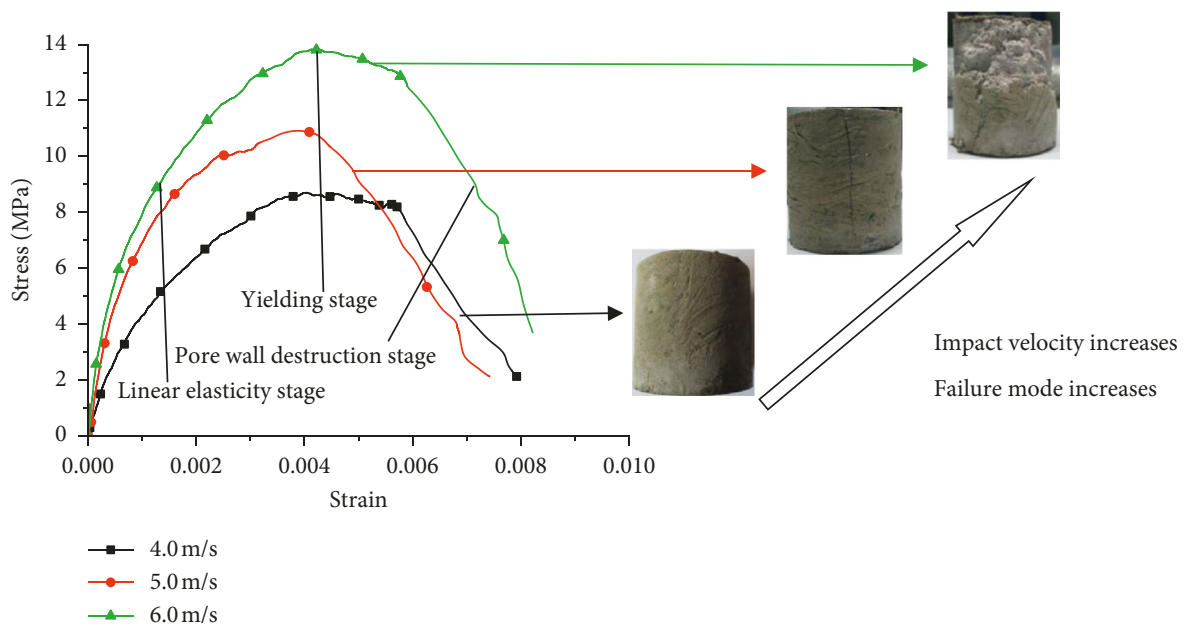

Figure 10: Foam concrete with sand stress-strain curve at $1,400 \mathrm{~kg} / \mathrm{m}^{3}$.

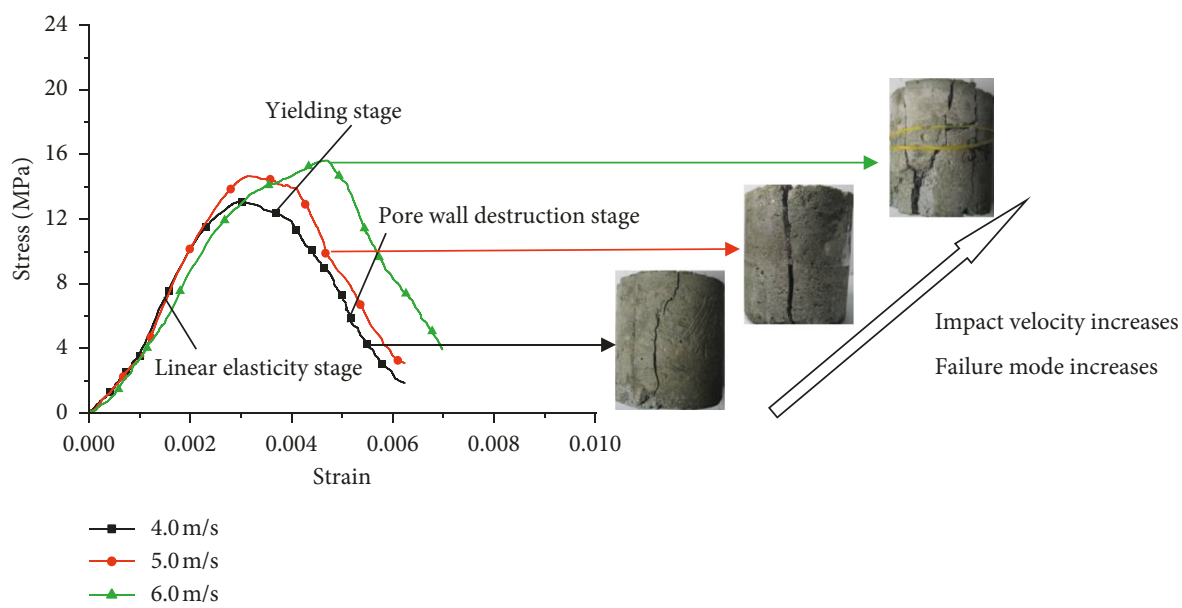

FIgURE 11: Foam concrete with fly ash stress-strain curve at $1,000 \mathrm{~kg} / \mathrm{m}^{3}$.

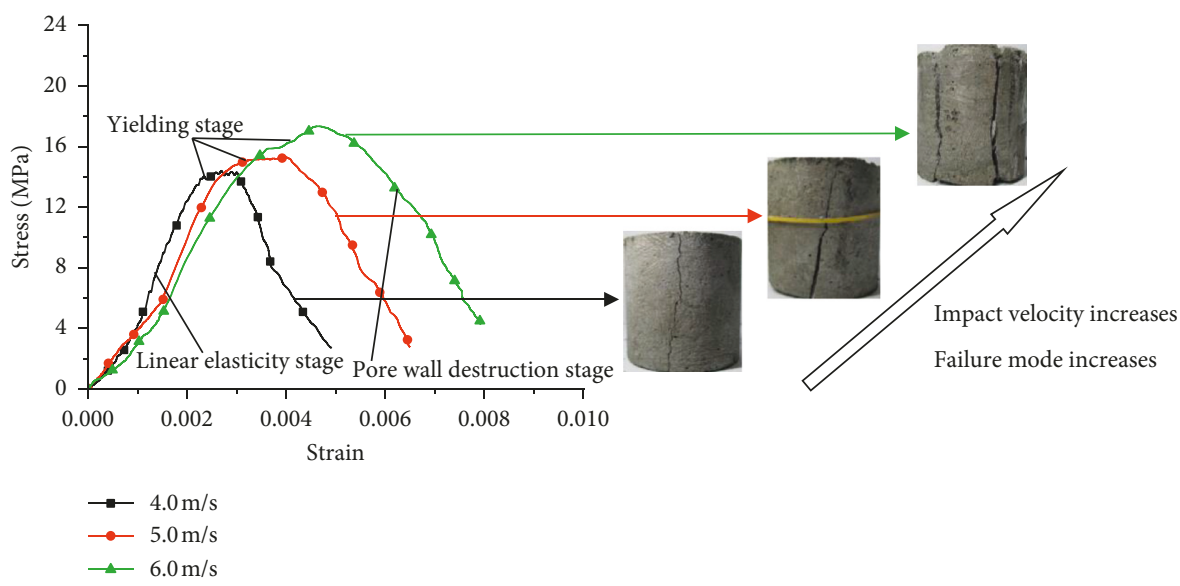

FIgURE 12: Foam concrete with fly ash stress-strain curve at $1,200 \mathrm{~kg} / \mathrm{m}^{3}$.

was correlated with the strain rate when the strain rate was $10-100 \mathrm{~s}^{-1}$. The degree of fragmentation also increased.

For porous materials similar to foam concrete, the strain rate dependence of their dynamic mechanical properties is due mainly to the presence of gas within the cavities. Hence, when compression was applied, the contact resistance of the pore walls within the foam concrete produced collision resistance, which increased the energy loss and accelerated 


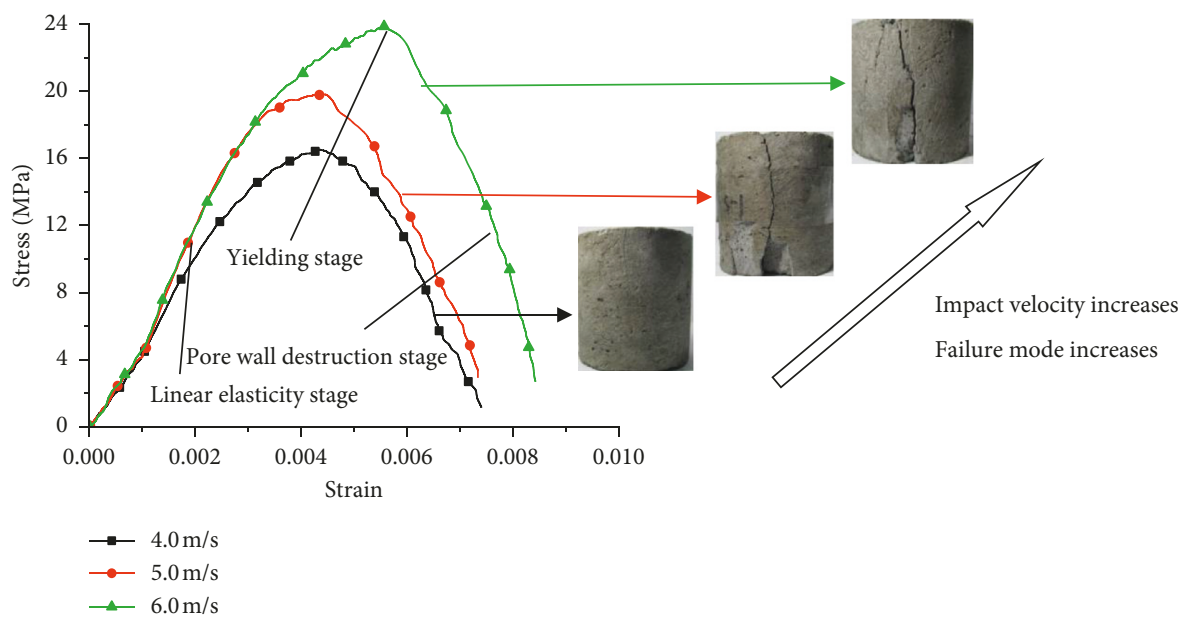

FIgURE 13: Foam concrete with fly ash stress-strain curve at $1,400 \mathrm{~kg} / \mathrm{m}^{3}$.

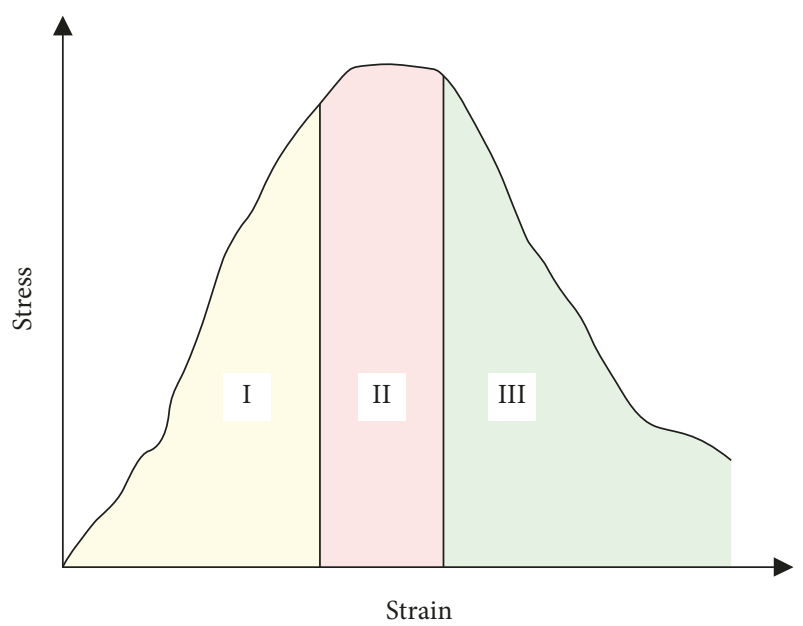

Figure 14: Three stages of dynamic failure of foam concrete.

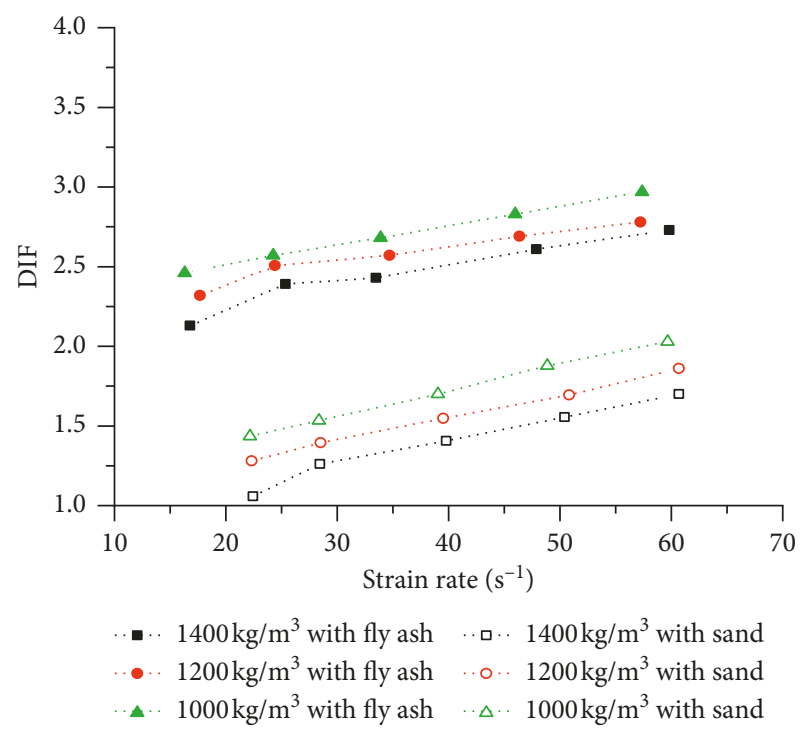

FIGURE 15: Relationship between the dynamic increase factor (DIF) and strain rate. the dynamic compressive strength of the foam concrete specimens.

4.3.3. Density and Ultimate Compressive Strength. Kearsley and Wainwright [18] showed that the ultimate compressive strength of foam concrete under static loading decreases exponentially with decreasing density. In this experiment, the specimen density had a significant effect on the mechanical properties of foam concrete. Figure 17 shows a comparison among the relationships between the ultimate compressive strength and density for specimens with different densities. For these different specimens, a lower density of the foam concrete resulted in a more porous interior, and an increase in the number of voids within the foam concrete led to more hole defects, thereby reducing the macrodensity of the specimen. The ultimate compressive strength of foam concrete increased with increasing density at the same impact velocity. In addition, the ultimate compressive strength of the foam concrete with fly ash was higher than that of the foam concrete with sand.

4.3.4. Impact Toughness. From a macroscopic perspective, toughness can be defined as the ability of a material to absorb energy from loading to failure; thus, toughness is a combination of both material strength and ductility. Impact toughness is related to not only the strength of the material but also the strain when the material is damaged. The strain energy density at the time of failure can be obtained by integrating the stress-strain curve area before the stress is removed. Because toughness reflects an eigenvalue stress, the complete mechanical response of the material before the strain is applied is not a single eigenvalue, and the experimental error produces a smaller discrepancy with higher data reliability.

The tenacity (RP) is the area between the stress-strain curve and the strain axis, and the specific energy absorption (SEA) is the stress wave energy absorbed by the foam concrete. The SEA takes many experimental factors into consideration, and thus, the result is closer to the actual 


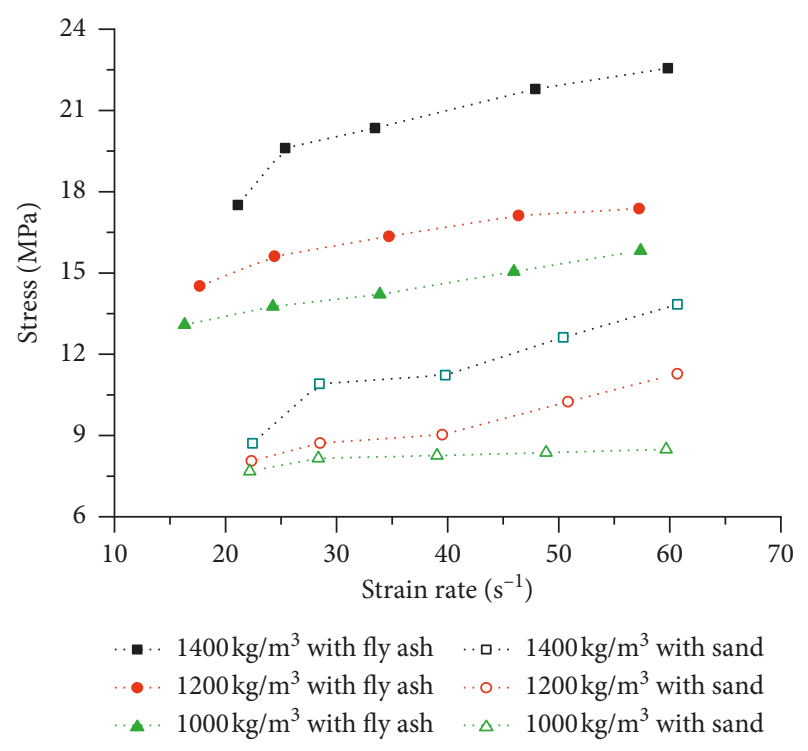

FIgURE 16: Relationship between the strain rate and ultimate compressive strength.

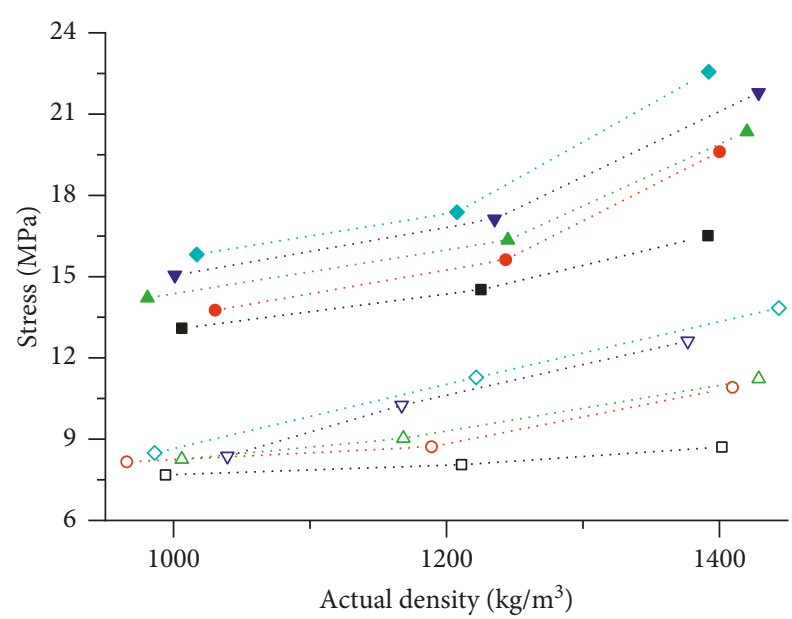

- - $2.0 \mathrm{~m} / \mathrm{s}$ with fly ash

- . $2.5 \mathrm{~m} / \mathrm{s}$ with fly ash

A. - $3.0 \mathrm{~m} / \mathrm{s}$ with fly ash

- . $3.3 \mathrm{~m} / \mathrm{s}$ with fly ash

- $4.2 \mathrm{~m} / \mathrm{s}$ with fly ash

‥ $2.0 \mathrm{~m} / \mathrm{s}$ with sand

. $0.2 .5 \mathrm{~m} / \mathrm{s}$ with sand

$\triangle \cdot . \cdot 3.0 \mathrm{~m} / \mathrm{s}$ with sand

$\nabla \cdot \cdot 3.3 \mathrm{~m} / \mathrm{s}$ with sand

$\diamond .2 \mathrm{~m} / \mathrm{s}$ with sand

FIGURE 17: Relationship between the actual density and ultimate compressive strength.

value of the material's impact toughness. Two kinds of impact toughness evaluation indices were chosen to analyse the foam concrete specimens. The relationships of the RP and SEA with the strain rate are shown in Figures 18 and 19, respectively. The peak toughness of foam concrete increased with an increasing strain rate. Two different relationships with the strain rate were considered here. According to Figures 18 and 19, the average strain rate continued to rise regardless of whether the RP or SEA was used as an indicator. Accordingly, these results reflect the consistency and rationality of these two indicators and demonstrate the reliability and stability of the results.
4.4. Comparison between Quasistatic and Dynamic Mechanical Behaviours. An electrohydraulic servo test system was used to test the $\varnothing 50 \times 100 \mathrm{~mm}$ cylindrical specimens. The two ends of the foam concrete were polished to reduce the friction between the pressing plate and foam concrete specimen, thereby reducing the friction on the transverse deformation during the test. From the beginning of loading to the maximum loading, the foam concrete did not crack. As the load was further increased to the maximum load, a small crack appeared in the middle and lower parts of the specimen. With further increases in the load and thus the stress, additional cracks began to appear; the specimen began to fracture as the cracks extended into the main cracks.

Figure 20 shows the quasistatic stress-strain curves of the foam concrete specimens with sand, and Figure 21 shows the quasistatic stress-strain curves of the foam concrete specimens with fly ash. Based on the quasistatic stress-strain curves of foam concrete with sand and foam concrete with fly ash shown in Figures 20 and 21, respectively, the stressstrain curve could be divided into three parts: an elastic state, a stress drop state, and a compaction state. With an increase in the specimen density, the stress increased gradually, but the effects of the stress did not increase significantly. The residual strength of the foam concrete with fly ash after crushing was very small. A large difference was observed relative to the strength of the foam concrete with sand; the greater the density was, the greater the residual strength was. Comparing the peaks of the stress-strain curves, the peaks for the foam concrete with fly ash were greater than those for the foam concrete with sand.

The material density of foam concrete had an influence on its mechanical properties. With an increase in the density, the yield strength, platform stress, and energy absorption capacity of the foam concrete obviously improved. The stress-strain behaviour appeared to be a function of the material composition and density. The stress increased with the density, and the foam concrete presented different characteristics when fly ash was used. The compressive strength of foam concrete with fly ash was higher than that of foam concrete with sand. The stress-strain curves exhibited different stages, which were interpreted as a function of the pore structure. The material strength is normally a function of the porosity, but in this paper, a $20 \%$ increase in density did not result in a significant increase in strength. This was related to the material, type of foaming agent, and curing process used in the preparation of foam concrete; in this study, this phenomenon was due mainly to the foaming agent.

The dynamic ultimate compressive strength of foam concrete was greater than the static ultimate compressive strength. Under quasistatic loading, foam concrete exhibited obvious ductility and toughness characteristics. The failure mode under quasistatic loading was compaction, and the dynamic failure mode was layer-by-layer collapse.

\section{Conclusions}

Foam concrete boasts certain advantages over ordinary concrete (e.g., a low density, an excellent thermal efficiency, 


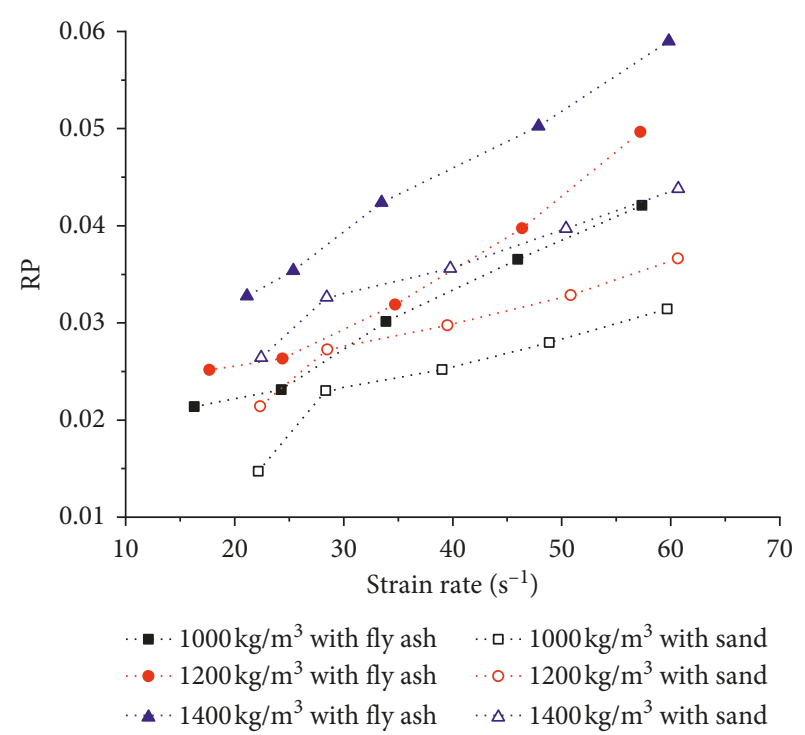

FIGURE 18: Relationship between the tenacity (RP) and the strain rate.

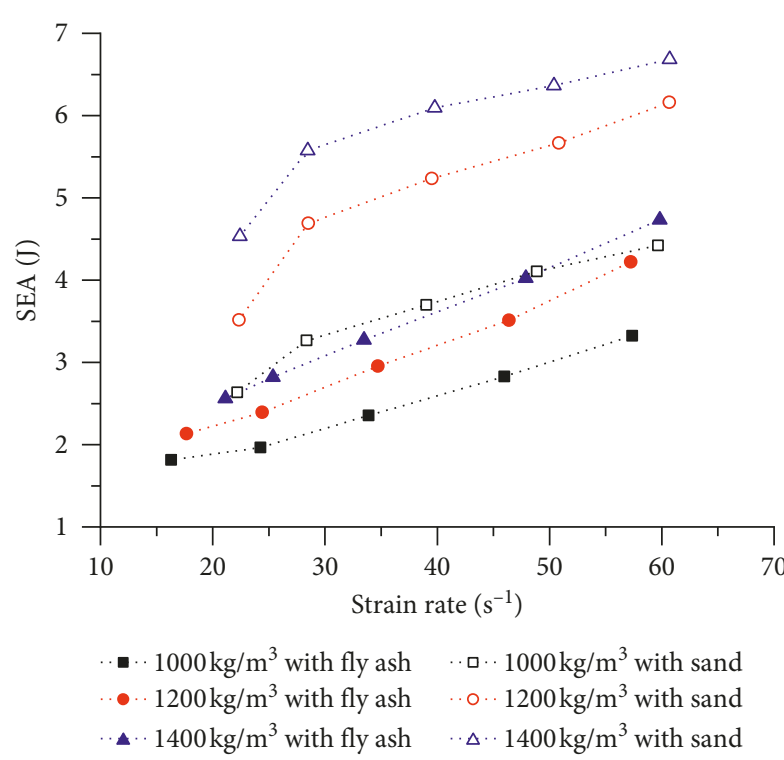

FIGURE 19: Relationship between the specific energy absorption (SEA) and the strain rate.

a high sound absorption capacity, and excellent flowability and self-compaction properties) that allow it to have a wide range of applications and a high research value. The dynamic mechanical properties of foam concrete under an impact load were analysed via static compression tests and dynamic impact tests. The relationships between the strength, deformation, impact toughness, and impact velocity of foam concrete were studied, and the failure modes of foam concrete were analysed. The following conclusions were drawn based on the results:

(1) The stress-strain curves of the foam concrete exhibited a strain platform due to the absorption of a large amount of energy in both static compression

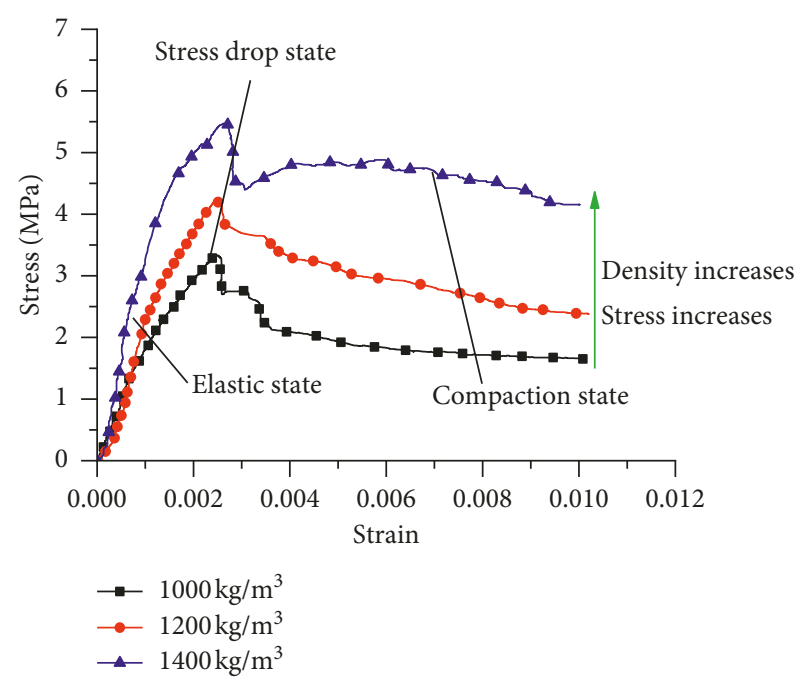

FIGURE 20: Quasistatic stress-strain curves of the foam concrete with sand.

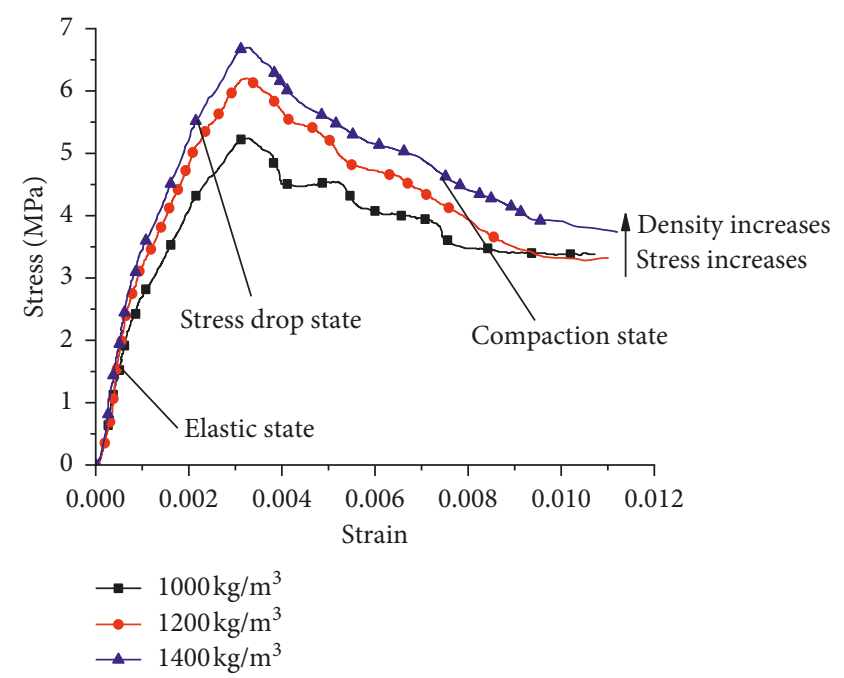

FIGURE 21: Quasistatic stress-strain curves of the foam concrete with fly ash.

and dynamic impact tests. This finding provides a reference for further research on the use of foam concrete as a soft structure in underground coal mines subjected to dynamic loading.

(2) In the static compression test, the stress of the foam concrete increased with increasing density. Under the same density, the stress of the foam concrete without fly ash was lower than that of the foam concrete with fly ash.

(3) In the dynamic impact test, the stress-strain curve of foam concrete was divided into a linear elastic stage, a yield stage, and a pore wall destruction stage. Under the same impact speed, the degree of damage became increasingly serious with increasing density. At the same density, the degree of damage increased with an increase in the impact velocity. 
(4) In the dynamic loading test, the dynamic compressive strength of foam concrete increased with an increase in the strain rate. The degree of fragmentation also increased, showing a significant correlation with the strain rate. The relationship between the DIF and relevant strain rate exhibited a significant damage softening effect. Furthermore, the impact toughness of foam concrete continuously increased with an increase in the average strain rate.

\section{Appendix}

The relationships between the cement-fly ash (sand)-bubblewater raw material in foam concrete are as follows:

$$
\begin{aligned}
& \rho_{\mp}=S_{\mathrm{a}}\left(M_{\mathrm{c}}+M_{\mathrm{fa}}\right), \\
& \rho_{\mp}=S_{\mathrm{a}}\left(M_{\mathrm{c}}+M_{\mathrm{s}}\right), \\
& M_{\mathrm{w}}=\varphi\left(M_{\mathrm{c}}+M_{\mathrm{fa}}\right), \\
& M_{\mathrm{w}}=\varphi M_{\mathrm{c}}, \\
& M_{\mathrm{fa}}=\lambda M_{\mathrm{c}}, \\
& M_{\mathrm{s}}=\lambda M_{\mathrm{c}},
\end{aligned}
$$

where $\rho_{\mp}$ is the design density of foam concrete $\left(\mathrm{kg} / \mathrm{m}^{3}\right), S_{\mathrm{a}}$ is the mass coefficient determined for the total amount of each component and the nonevaporable material in the foam concrete (for ordinary Portland cement, the value is 1.2), $M_{c}$ is the amount of cement used in every cube of foam concrete $(\mathrm{kg}), M_{\mathrm{fa}}\left(M_{\mathrm{s}}\right)$ is the amount of fly ash (sand) used in every cube of foam concrete $(\mathrm{kg}), M_{\mathrm{w}}$ is the water consumption in every cube of foam concrete $(\mathrm{kg}), \varphi$ is the cement water ratio (0.5), and $\lambda$ is the rate of fly ash (sand) replacement.

The total volume of slurry consisting of cement, fly ash (sand), and water is $V_{1}$, and the amount of foam in every cube of foam concrete is $V_{2}$ :

$$
\begin{aligned}
& V_{1}=\frac{M_{\mathrm{fa}}}{\rho_{\mathrm{fa}}}+\frac{M_{\mathrm{c}}}{\rho_{\mathrm{c}}}+\frac{M_{\mathrm{w}}}{\rho_{\mathrm{w}}}, \\
& V_{2}=k\left(1-V_{1}\right),
\end{aligned}
$$

where $\rho_{\mathrm{fa}}\left(\rho_{\mathrm{s}}\right), \rho_{\mathrm{c}}$, and $\rho_{\mathrm{w}}$ are the densities of fly ash (sand), cement, and water, respectively. $k$ is the wealth factor and is typically between 1.1 and 1.4 .

The amount of foam agent is expressed as

$$
M_{\mathrm{f}}=M_{\mathrm{h}} \frac{V_{2}}{\beta \cdot 0.0224},
$$

where $M_{\mathrm{f}}$ is the amount of foam agent in every cube of foam concrete, $M_{\mathrm{h}}$ is the amount of foam agent generated per $1 \mathrm{~mol}(22.4 \mathrm{~L})$ of gas according to the chemical reaction equation, and $\beta$ is the purity of the foaming agent.

For $1000 \mathrm{~kg} / \mathrm{m}^{3}$ foam concrete with sand, the calculation $\left(1 \mathrm{~m}^{3}\right)$ is as follows:
The total mass of cement and sand is $1000 \mathrm{~kg} /$ $1.2=833.3333 \mathrm{~kg}$.

The mass fraction of sand substituted for the cement tested was 0.2 . The mass of sand is $833.3333 \mathrm{~kg} * 0.2=$ $166.6667 \mathrm{~kg}$.

The mass of cement is $833.3333 \mathrm{~kg}-166.6667 \mathrm{~kg}=$ $666.6666 \mathrm{~kg}$.

The cement water ratio is 0.5 .

The mass of water is $666.6666 \mathrm{~kg} * 0.5=333.3333 \mathrm{~kg}$.

The total volume of slurry consisting of cement, sand, and water is $166.6667 \mathrm{~kg} / 2,520 \mathrm{~kg} / \mathrm{m}^{3}+666.6666 \mathrm{~kg} /$ $3,150 \mathrm{~kg} / \mathrm{m}^{3}+333.3333 \mathrm{~kg} / 1,000 \mathrm{~kg} / \mathrm{m}^{3}=0.6111 \mathrm{~m}^{3}$.

The amount of foam in every cube of foam concrete is $1.4 *\left(1-0.6111 \mathrm{~m}^{3}\right)=0.5445 \mathrm{~m}^{3}$.

The chemical equation of $\mathrm{H}_{2} \mathrm{O}_{2}$ (hydrogen peroxide) is $2 \mathrm{H}_{2} \mathrm{O}_{2} \cdot \mathrm{H}_{2} \mathrm{O}+\mathrm{O}_{2} \longrightarrow \mathrm{H}_{2} \mathrm{O}+\mathrm{O}_{2}$

2 moles of $\mathrm{H}_{2} \mathrm{O}_{2}$ can release 1 mole of $\mathrm{O}_{2}$, which means every $68 \mathrm{~g}$ of $\mathrm{H}_{2} \mathrm{O}_{2}$ can release $22.4 \mathrm{~L} \mathrm{O}_{2}$.

The mass of $\mathrm{H}_{2} \mathrm{O}_{2}$ is $0.068 * 0.5445 / 0.0224=1.6529 \mathrm{~kg}$.

The mass of foam agent is $1.30 \mathrm{~kg} / 0.3=5.5098 \mathrm{~kg}$.

Sum of Masses: $666.6666 \mathrm{~kg}+166.6667 \mathrm{~kg}+333.3333 \mathrm{~kg}$ $+5.5098 \mathrm{~kg}=1172.1764 \mathrm{~kg}$

Sum of Volumes: $0.6111 \mathrm{~m}^{3}+0.5445 \mathrm{~m}^{3}=1.1556 \mathrm{~m}^{3}$

Obtained density: $1014.34 \mathrm{~kg} / \mathrm{m}^{3}$.

To obtain a specific design foam concrete density, need to adjust successively the input density until obtaining the output density equal to the design density.

\section{Data Availability}

The data used to support the findings of this study are available from the corresponding author upon request.

\section{Conflicts of Interest}

The authors declare that there are no conflicts of interest regarding the publication of this paper.

\section{Acknowledgments}

The authors would like to acknowledge the financial support provided by the Postgraduate Research \& Practice Innovation Program of Jiangsu Province (KYCX19_2130), the National Natural Science Foundation Project of China (51564044), and the State Key Laboratory of Coal Resources and Safe Mining, China University of Mining and Technology (SKLCRSM15X02 and SKLCRSM18KF004).

\section{References}

[1] K. Mikulica and M. Labaj, "Foam concrete gravity wedges as a thermal insulation of flat roofs," Key Engineering Materials, vol. 722, pp. 331-336, 2016.

[2] L. Cox and S. van Dijk, "Foam concrete for roof slopes and floor levelling," Concrete, vol. 37, no. 2, pp. 37-39, 2003. 
[3] D. G. Chen, Y. Yao, H. J. Wang, Y. P. Zhu, and J. L. Zou, "Experiment research on thermal performance of foam concrete wall," Applied Mechanics and Materials, vol. 488489, pp. 609-613, 2014.

[4] X. Tan, W. Chen, H. Liu et al., "A combined supporting system based on foamed concrete and U-shaped steel for underground coal mine roadways undergoing large deformations," Tunnelling and Underground Space Technology, vol. 68, pp. 196-210, 2017.

[5] L. P. Priddy and J. S. Tingle, "Development of expedient military concrete airfield pavement repairs," Magazine of Concrete Research, vol. 66, no. 1, pp. 25-35, 2014.

[6] C. Pickford and S. Crompton, "Foamed concrete in bridge construction," Concrete, vol. 30, no. 6, pp. 14-15, 1996.

[7] I. A. Lundyshev, "Experimental investigation of technologie of pipelines thermal protection by monolithic foam concrete," Magazine of Civil Engineering, vol. 15, no. 5, pp. 49-52, 2010.

[8] M. S. Gao, L. M. Dou, and N. Zhang, "Strong-soft-strong mechanical model for controlling roadway surrounding rock subjected to rock burst and its application," Rock and Soil Mechanics, vol. 29, no. 2, pp. 359-364, 2008.

[9] K. Ramamurthy, E. K. Kunhanandan Nambiar, and G. Indu Siva Ranjani, "A classification of studies on properties of foam concrete," Cement and Concrete Composites, vol. 31, no. 6, pp. 388-396, 2009.

[10] M. Jones and A. McCarthy, "Utilising unprocessed low-lime coal fly ash in foamed concrete," Fuel, vol. 84, no. 11, pp. 1398-1409, 2005.

[11] Q. Li, Y. Ge, and W. Yang, "Effect of sodium sulfate and sodium nitrite on air-void system in air-entrained concrete," Magazine of Concrete Research, vol. 68, no. 23, pp. 1200-1209, 2016.

[12] K. Habel, M. Viviani, E. Denarié, and E. Brühwiler, "Development of the mechanical properties of an ultra-high performance fiber reinforced concrete (UHPFRC)," Cement and Concrete Research, vol. 36, no. 7, pp. 1362-1370, 2006.

[13] Z. Liu, Y. Zhang, and Q. Jiang, "Continuous tracking of the relationship between resistivity and pore structure of cement pastes," Construction and Building Materials, vol. 53, pp. 26-31, 2014.

[14] T. H. Wee, D. S. Babu, T. Tamilselvan et al., "Air-void system of foamed concrete and its effect on mechanical properties," ACI Materials Journal, vol. 103, no. 1, pp. 45-52, 2006.

[15] K. G. Babu and D. S. Babu, "Behaviour of lightweight expanded polystyrene concrete containing silica fume," Cement and Concrete Research, vol. 33, no. 5, pp. 755-762, 2003.

[16] D. K. Panesar, "Cellular concrete properties and the effect of synthetic and protein foaming agents," Construction and Building Materials, vol. 44, pp. 575-584, 2013.

[17] D. Falliano, D. De Domenico, G. Ricciardi, and E. Gugliandolo, "Experimental investigation on the compressive strength of foamed concrete: effect of curing conditions, cement type, foaming agent and dry density," Construction and Building Materials, vol. 165, pp. 735-749, 2018.

[18] E. P. Kearsley and P. J. Wainwright, "The effect of high fly ash content on the compressive strength of foamed concrete," Cement and Concrete Research, vol. 31, no. 1, pp. 105-112, 2001.

[19] W. She, Y. Du, G. Zhao, P. Feng, Y. Zhang, and X. Cao, "Influence of coarse fly ash on the performance of foam concrete and its application in high-speed railway roadbeds," Construction and Building Materials, vol. 170, pp. 153-166, 2018.
[20] E. K. K. Nambiar and K. Ramamurthy, "Air-void characterisation of foam concrete," Cement and Concrete Research, vol. 37, no. 2, pp. 221-230, 2007.

[21] M. R. Jones and A. McCarthy, "Preliminary views on the potential of foamed concrete as a structural material," Magazine of Concrete Research, vol. 57, no. 1, pp. 21-31, 2005.

[22] A. Hajimohammadi, T. Ngo, P. Mendis, T. Nguyen, A. Kashani, and J. S. J. van Deventer, "Pore characteristics in one-part mix geopolymers foamed by $\mathrm{H}_{2} \mathrm{O}_{2}$ : the impact of mix design," Materials \& Design, vol. 130, pp. 381-391, 2017.

[23] C. Ma and B. Chen, "Experimental study on the preparation and properties of a novel foamed concrete based on magnesium phosphate cement," Construction and Building $M a$ terials, vol. 137, pp. 160-168, 2017.

[24] Y. P. Liu, T. H. Wu, Z. J. Liu, Z.-Y. Jiang, and L.-Q. Tang, "A constitutive model of foam-filled concrete under quasi-static compression," Journal of South China University of Technology, vol. 44, no. 10, pp. 49-56, 2016, in Chinese.

[25] J. Zhu and Y. X. Xie, "Study on strength and strain of foam concrete," Concrete, vol. 251, no. 9, pp. 124-126, 2010, in Chinese.

[26] W. L. Tian, J. B. Yang, and X. Y. Zhao, "Study on properties of foam concrete based on fractal theory," Advanced Materials Research, vol. 194-196, pp. 1916-1919, 2011.

[27] A. R. Bagheri, T. Parhizkar, and A. M. R. Ghasemi, "Foam concrete: properties and application areas," in Proceedings of the Annual Conference-Canadian Society for Civil Engineering, vol. 4, pp. 101-110, Regina, Canada, June 1999.

[28] M. Gao, H. Zhao, Y. Zhao, X. Gao, and X. Wang, "Investigation on the vibration effect of shock wave in rock burst by in situ microseismic monitoring," Shock and Vibration, vol. 2018, Article ID 8517806, 14 pages, 2018.

[29] Z. J. Yan and Y. J. He, Practical Production Technology of Foamed Concrete, Chemical Industry Press, Beijing, China, 2006.

[30] M. Pankow, C. Attard, and A. M. Waas, "Specimen size and shape effect in split Hopkinson pressure bar testing," Journal of Strain Analysis for Engineering Design, vol. 44, no. 8, pp. 689-698, 2009.

[31] S. H. Li, W. C. Zhu, L. L. Niu, M. Yu, and C. F. Chen, "Dynamic characteristics of green sandstone subjected to repetitive impact loading: phenomena and mechanisms," Rock Mechanics and Rock Engineering, vol. 51, no. 6, pp. 1921-1936, 2018.

[32] E. Kuzielová, L. Pach, and M. Palou, "Effect of activated foaming agent on the foam concrete properties," Construction and Building Materials, vol. 125, pp. 998-1004, 2016.

[33] J. M. Lifshitz and H. Leber, "Data processing in the split Hopkinson pressure bar tests," International Journal of Impact Engineering, vol. 15, no. 6, pp. 723-733, 1994.

[34] L. M. Yang and V. P. W. Shim, "An analysis of stress uniformity in split Hopkinson bar test specimens," International Journal of Impact Engineering, vol. 31, no. 2, pp. 129-150, 2005.

[35] K. Ramamurthy and N. Narayanan, "Factors influencing the density and compressive strength of aerated concrete," Magazine of Concrete Research, vol. 52, no. 3, pp. 163-168, 2000. 


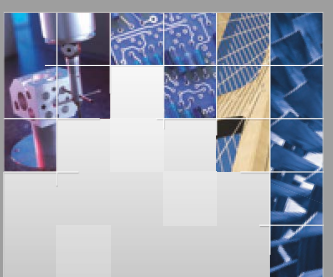

\section{Enfincering}
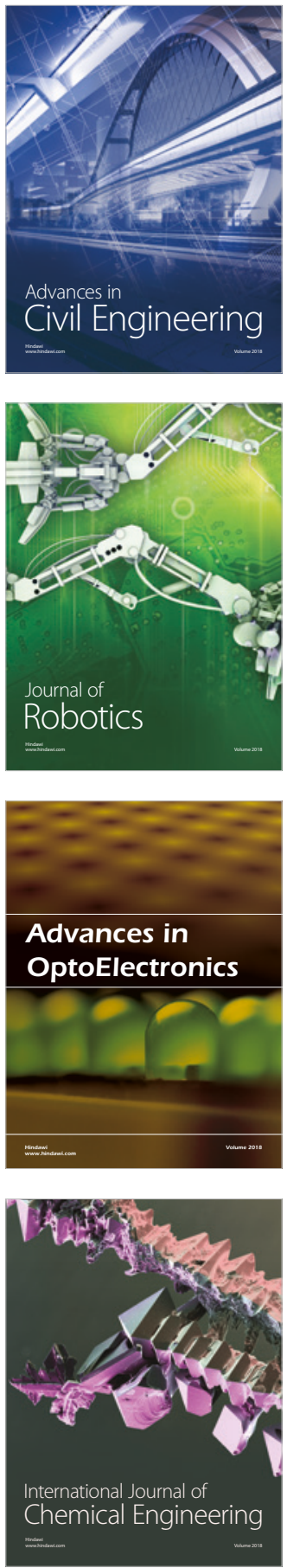

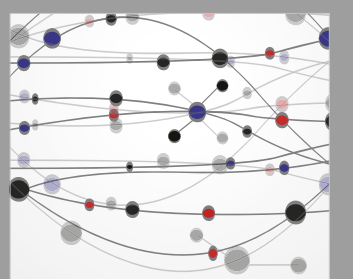

\section{Rotating \\ Machinery}

The Scientific World Journal

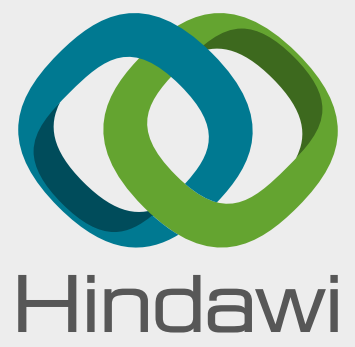

Submit your manuscripts at

www.hindawi.com
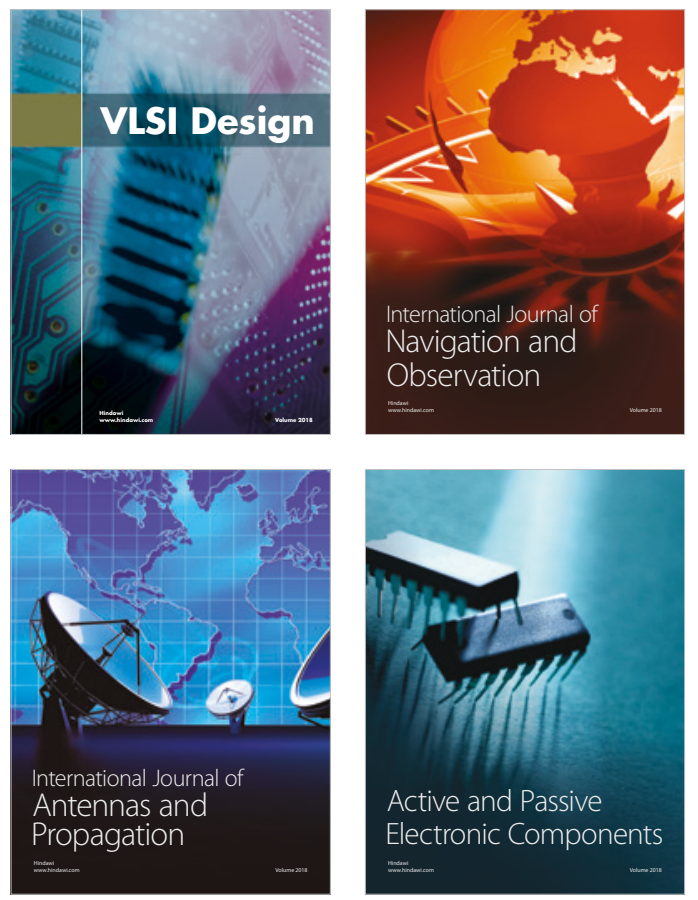
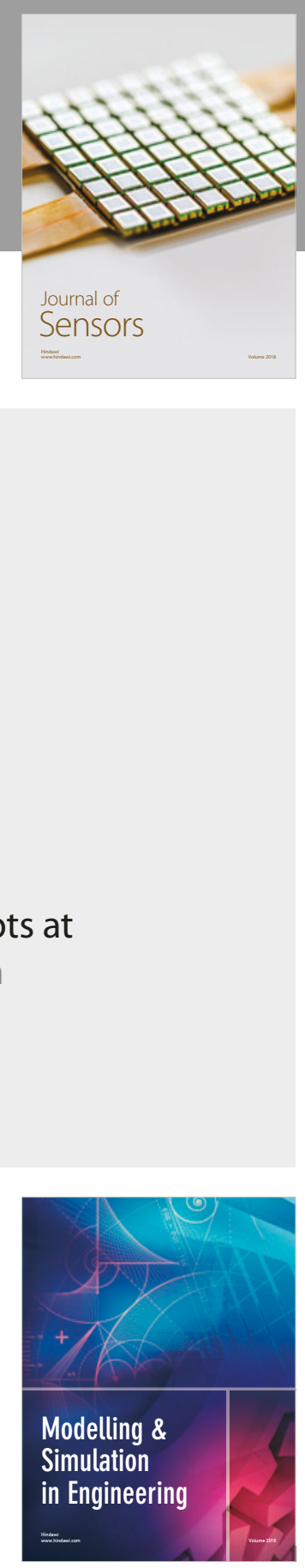

\section{Advances \\ Multimedia}
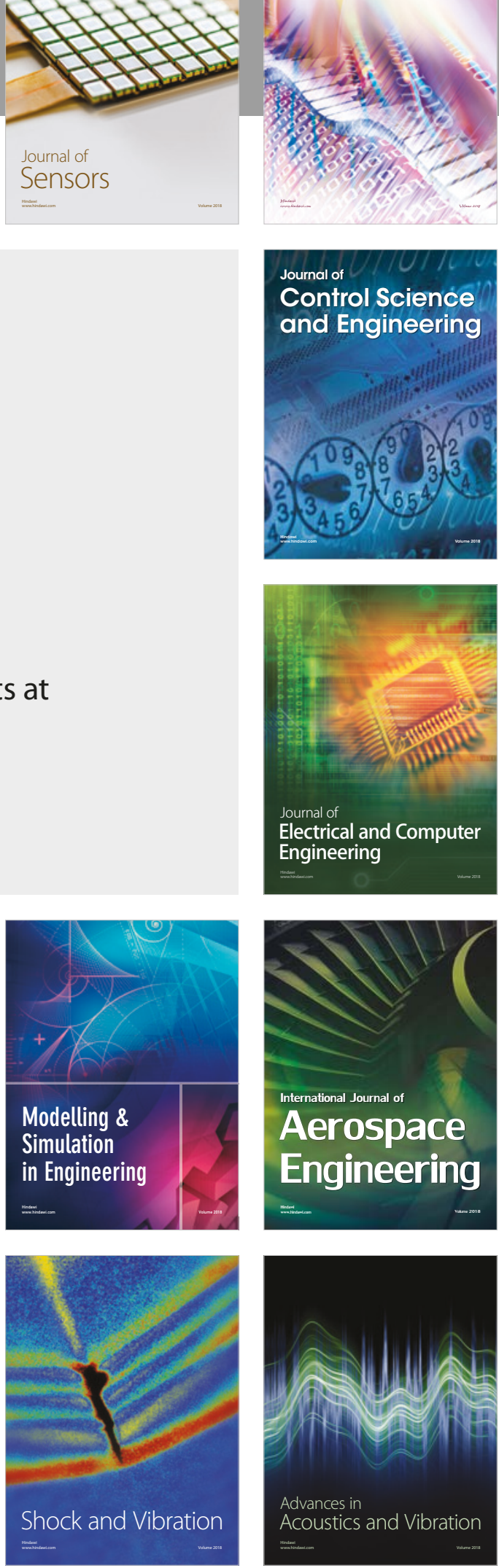